EWA BADZIŃSKA

Poznań University of Technology, Polan

\title{
Experiential and result-driven entrepreneurship education: evidence from an international project
}

\begin{abstract}
The search for effective learning pathways and transformative changes in both the conceptual and curricular field and technological areas are significant challenges for higher education institutions (HEIs). Although a wide range of methods, tools, and interactive channels are available to shape an entrepreneurial mindset, students need clear objectives and understanding embedded in multidisciplinary knowledge and transferable competencies to implement practical business practice solutions. The article's main objective is to present an experiential and result-driven approach to entrepreneurship education that aims to support students in solving real business problems by interacting with the local environment. The participatory co-creation process involved international students (147 participants from 16 nationalities), and the three cycles of two-week intensive programmes (2017-2019) were carried out within the framework of the international project ECMT+. This experimental education process is presented here using the case study method based on the author's experience, observation and reflection. The study reveals that hands-on activities designed for the project positively affected student learning outcomes and motivated them to acquire entrepreneurial competencies. However, entrepreneurship education has to be more inclusive and develop good practice to meet local needs and more diverse learners.
\end{abstract}

Keywords: entrepreneurship education; experiential learning; intercultural collaboration; result-driven education

Received: 3 November 2020

Accepted: 4 March 2021

\section{Suggested citation:}

Badzińska, E. (2021). Experiential and result-driven entrepreneurship education: evidence from an international project. Przedsiębiorczość - Edukacja [Entrepreneurship - Education], 17(1), 77-89. https://orcid.org/10.24917/20833296.171.6

\section{Introduction}

Transformative changes, both in conceptual and curricular areas and technology, are an essential aspect in discussing the quality of education at higher education institutions 
(HEIs) and the appropriate preparation of students for the labour market. Consequently, universities face challenges that require them to rethink their strategies, become more entrepreneurial and open to cooperation with stakeholders to provide students with the most up-to-date professional knowledge and transferable skills appropriate to the requirements of the labour market. Thus, universities have to be more active actors and linked to their external environment through a strong presence and commitment in the local community. They can, for example, provide support for local start-ups and companies in the development phase with a great potential for local development, participate in regional clusters or entrepreneurial initiatives, and take an active role in determining the strategic direction of their region (OECD, 2012). In this respect, different HEIs worldwide take action to stimulate learning opportunities against the broader socio-economic and cultural context to promote entrepreneurial endeavours.

Formal entrepreneurship education has been shown to have a significant impact on students' propensity for entrepreneurship and entrepreneurial intentions. It therefore remains a subject of debate by many academics both abroad (Bacigalupo et al., 2016; Fayolle, Gailly, 2013; Lackéus, 2015; Raposo, Paço, 2011) and at home (Bratnicki et al., 2007; Cieślik, 2008, 2010; Kwiatkowski, 2018; Matusiak et al., 2011; Rachwał, 2019; Wach, 2013; Zioło, 2012). Universities try to integrate entrepreneurship education into the curricula using various methods, tools and learning speeds, depending on the availability of expertise and resources. Unfortunately, there is no single best way, so good practice needs to be searched. In this context, an approach based on experiential learning and result-driven entrepreneurship education at HEIs can help shape the desired competencies and skills. Moreover, reciprocal learning and sharing between teachers and professionals from working life offer one channel, even a small one, to local business entities to cooperate and build connections within a diverse network. This, in turn, feeds back into the regional entrepreneurial ecosystem (Badzińska, Timonen, 2019: 12). Thus, the key to effective entrepreneurship education is to find the best match between student needs and local and regional development and teaching methods and techniques.

To contribute to the spread of practice in the field of entrepreneurship education at HEIs, and to enhance pedagogical effectiveness, this article, inspired by the prior work of the author on practice-oriented learning and teaching in multicultural teams (Badzińska, 2017, 2019; Badzińska, Timonen, 2019, 2020), attempts to advance a framework of experiential learning and result-driven entrepreneurship education. It takes an integrative approach to the methods and tools elaborated and adapted within the Erasmus+ Strategic Partnership Project titled Entrepreneurship and Communication in Multicultural Teams $(E C M T+)^{1}$ and provides examples of business solutions designed by students.

The article's objective is to present an experiential and result-driven approach to entrepreneurship education within diverse international student teams, supporting them in solving real business problems. The conceptual discussion stems from Kolb's Experiential Learning Cycle (Kolb, 1984) and the Kolb Learning Style Inventory 4.0 (Kolb A.Y., Kolb D.A., 2013). The participatory co-creation process of students (147 participants of 16 nationalities) was to generate business models for solving real business problems by

${ }^{1}$ ECMT+ Entrepreneurship and Communication in Multicultural Teams is an Erasmus+ Strategic Partnership Project 2016-2019 (Agreement 2016-1-FI01-KA203-022743). The partners of the consortium represent seven European higher education institutions from Belgium, Czech Republic, Finland, France, Germany, Poland, and the United Kingdom, for more see: www.ecmt-plus.eu. 
interacting with the local environment. ECMT+ project partners carried out three cycles of two-week intensive programmes (2017-2019). The discussion reflects the main findings gathered within student-oriented and result-driven entrepreneurship workshops and is based on the author's experience, observation and reflection.

The applied exploratory study's originality lies in presenting real experiential learning and the teaching process, methods, and learning content elaborated and applied by ECMT+ project partners. They worked together to develop students' entrepreneurial mindsets, teaching and learning practice, entrepreneurship research and intercultural communication skills (Bond et al., 2019; Badzińska, Timonen, 2020). Moreover, the contribution consists of designing a conceptual model for teaching and the learning process for a more effective result-driven entrepreneurship education based on the Kolb Learning Style Inventory 4.0 (Kolb A.Y., Kolb D.A., 2013).

Due to the qualitative, descriptive and mostly subjective nature of the research, the results cannot be generalised. The specific teaching and learning process presented is meant to be experimental and illustrative; therefore, it requires constant improvement and adaptation to current conditions in the education process at HEIs. Despite these limitations, this study illustrates real experiences of entrepreneurship education in an international context and can inspire future research on practice-oriented approaches and provide examples of good practice.

\section{Entrepreneurship education at HEls: challenging expectations}

Research on entrepreneurship education has abounded since the early 1990s (Bechard, Toulouse, 1998; Block, Stumpf, 1992; Fayolle, 2005; Katz, 2003; Kirby, 2004; Kuratko, 2005, among others) and continues to be expanded and validated for both secondary and higher education (Fayolle, 2013; Gaweł, Pietrzykowski, 2015; Kilar, Rachwał, 2019; Sánchez, 2013). The importance the European Union attaches to it was already underlined in the European Charter for Small Enterprises in 2000, which stated: "Europe will nurture entrepreneurial spirit and new skills from an earlier age. [...] Specific business-related modules should be made an essential ingredient of education schemes at the secondary level and colleges and universities" (Salzano, Bahri, Haftendorn, 2006: 21).

The subject literature indicates that entrepreneurship education encompasses diverse domains of activities, fields, and practice and demonstrates the increasing importance of entrepreneurial skills to manage the social, economic and environmental challenges of tomorrow. As early as the beginning of the $21^{\text {st }}$ century, researchers pointed to the need to develop or expand entrepreneurship education programmes (Kuratko, 2003). Due to the rapid dynamics of technological and economic development related to industry 4.0, the need to create unique and challenging curricula is still valid. All the more, effective entrepreneurship education is critical for developing the skills, attitudes, and behaviours that are a prerequisite for the country's innovative and competitive economy.

The major challenge for researchers and educators involved in entrepreneurship education is still the appropriateness of curricula and training programmes. New teaching models and approaches and technological opportunities (eLearning, mobile devices, learning networks, interactive educational platforms) offer various methods, tools, and communication channels. Unfortunately, the variety of offer is not always equalled by its quality. Many HEIs face this problem and are looking for practical teaching tools and 
methods, mainly due to the need to switch to distance learning due to the COVID-19 pandemic.

Furthermore, entrepreneurship education's role is to provide students with cognitive strategies that will enable them to see their way to self-development, define goals, and achieve business success (Welsh, Tullar, Nemati, 2016). Moreover, it can provide problem-solving techniques to help students get an idea of how the path to a business might work. Entrepreneurship is a particular type of attitude and mindset, a creative way of looking at the world towards self-development and fulfilment. However, in practice, many entrepreneurship courses do not prepare students for real business life, and the acquired competencies do not meet market needs or are insufficient. H. Matlay (2008), for example, found a mismatch between graduate needs for entrepreneurship education and actual outcomes in terms of entrepreneurial attitudes, transferable skills and business knowledge. Therefore, assessment studies are badly needed (Welsh, Tullar, 2014), which combine such education with a growing entrepreneurial propensity and then align it with a real-world entrepreneurial trajectory.

Furthermore, entrepreneurship education practice should integrate research findings and theory to be understood and applied by students. Thus, entrepreneurship research results could be linked to an offer to create a good practice guide and inspire both teachers and researchers to share their experiences and findings. For example, an open-access public platform in entrepreneurship could help test new research ideas, contribute to developing and spreading the use of innovative pedagogies, and provide feedback for the active researcher. Moreover, such access to practical knowledge can encourage teachers to follow up and reflect on their teaching methods, approaches and experimentation. Furthermore, combining result-driven entrepreneurship education with academic approaches can increase the attractiveness of teaching activities.

Undoubtedly, various formal and non-formal educational and training opportunities can affect entrepreneurial mindsets and skills. Based on this foundation, the ECMT+ consortium partners developed three series of interdisciplinary workshops for experiential and result-driven entrepreneurship education to provide students with a mix of transferable skills and three series of teacher training events ${ }^{2}$ to share good teaching practice at HEIs. In turn, the project entitled "The acceleration method of development of transferable competencies in the students' practical training process" can serve as an excellent example for academic practice in developing professional competencies (Szafrański, Goliński, Simi, 2017)3. Thus, HEIs can help create a more entrepreneurial mindset among students by instilling a clear understanding of risks and rewards by teaching the ability to seek and recognise opportunities and creating successful enterprises.

Another critical issue is the availability of educational services that provide examples of good practice in teaching and learning entrepreneurship worldwide and showcase different institutional approaches on an ongoing basis. In response to this expectation, the European Commission and the OECD jointly support the HEInnovate online platform's development ${ }^{4}$. It is a self-assessment tool for HEIs who wish to explore their innovative potential and improve their educational programmes. HEInnovate provides learning materials, case

\footnotetext{
${ }^{2}$ More about the Intensive Programmes and Teacher Training Events see: http://www.ecmt-plus.eu/ events/.

${ }^{3}$ More about this project see: http://www.awt.org.pl/projekty/erasmus/?lang=en.

${ }^{4}$ More about the HEInnovate see: https://heinnovate.eu/en.
} 
studies and a pool of experts. A new entrepreneurship education service - entreTime should be highlighted as it aims to increase teachers' competencies and skills while upgrading their pedagogical tools in a given field by providing them with a comprehensive training package. entreTime is a unique academic platform for spreading entrepreneurial teaching and co-creation by engaging top-level educators across Europe.

Numerous HEIs, mainly technical and business ones, are looking to play an influential role in creating a more entrepreneurial society and environment (Kirby et al., 2011). This, in turn, reflects expectations regarding the contribution of universities to regional development by linking appropriate organisational environments and resources (Guerrero, Urbano, 2011) and adapting their core activities related to research, teaching and an entrepreneurial mission to market needs. In this context, entrepreneurship education and start-up incubation programmes (Świeszczak, 2016) provide a way of taking on social responsibility and generating local competitive advantage by supporting new venture creation. The university-business collaboration should contribute to creating new multidisciplinary curricula and the promotion of transferable skills and entrepreneurial attitudes within and through education (Badzińska, Timonen, 2020: 9). Moreover, entrepreneurship education must prepare students to believe that failure is part of business life. Therefore, completing an entrepreneurship course or searching for a business model is just the first in a series of opportunities or steps in becoming an entrepreneur. Students and university graduates must learn to "see entrepreneurship as a journey rather than a destination: a sequence of occasions as opposed to an outcome" (Welsh et al., 2016: 127).

\section{Materials and methods}

The exploratory research objective covers students' experiential learning, the participatory co-creation process for a business model, and reflections on entrepreneurship education outcomes during the three cycles of intensive programmes (IPs) 2017-2019. The workshops were carried out once a year by the ECMT+ project partners, at the Karelia University in Joensuu (2017), Technical University of Applied Sciences in Wildau (2018), and Université Jean Monnet Saint-Étienne in Roanne (2019), and focused on practice, research and education underlining the entrepreneurial performance in the local environment. The IPs involved an intensive two weeks of working together with both students (46-48 participants each time of 14 to 16 nationalities) and teachers/coaches (about 25 each time) from seven different European HEIs in order to develop transferable skills and business knowledge using experiential learning activities and result-driven approaches. Furthermore, practitioners and entrepreneurs from the local business environment shared their success factors and failure management with workshop participants. Students involved in workshops were exposed to exact customer needs, expectations and market demand.

The IP's participants were selected by a purposeful sampling technique (Patton, 2002). S. Shane and S. Venkataraman (2000) emphasise that entrepreneurship research should focus on individuals with a unique vision and perspective on improving the world and who are engaged in the discovery and exploitation of opportunities to create added value. Following this line, the selection of students carried out by project partners was based on their willingness for self-development, commitment and creativity in generating innovative business solutions, discovering entrepreneurial opportunities, and overcoming 
possible difficulties and prejudices. Moreover, essential selection criteria were openness to new challenges, diversity of international students and inclusion.

This study briefly discusses the process and specific experiential teaching stages and learning using the case study method. The rationale for its use is its value related to building an understanding of phenomena in a selected context under actual conditions (Merriam, 1998; Yin, 2014). Furthermore, there is a need to conduct practice-oriented empirical research to better understand the surrounding reality (Czakon, 2015). The knowledge and competency development process included three intensive entrepreneurship workshops and reflections on learning, teaching and research.

The conceptual discussion uses (among other studies) the competency development framework in entrepreneurship education by Lackéus (2015) and the new Kolb Learning Styles Inventory 4.0 (Kolb, Kolb, 2013), which both contribute to meaningful teaching practice and support learner experience. A.Y. Kolb and D.A. Kolb (2013) emphasise that the learning process is cyclical, and while students are learning specific content and subjects, it is equally important to reflect consciously and get to know individual learning processes. Thus, the tasks should be adapted to the right and most meaningful level of involvement for students. Moreover, "reflection involves building a self-identity and self-concept around an entrepreneurial life. [...] This is an important way to create self-coherence, a positive self-concept and high self-esteem" (Welsh, Tullar, Nemati, 2016: 126). The findings of the analysis of reflection diaries created by IP participants are presented in the works of Badzińska (2017) and Heinz, Chylková, Nenička (2018).

This study is limited to the explorations carried out by the author, involved in the competency development process within the ECMT+, and which was for her at the same time an experiential learning opportunity as she examined her working environment and learned from this experience. In turn, the holistic approach to student learning and reciprocal teaching included participatory observation, reflection and analysis, and evaluation of the whole experiential learning process. In this study, the iterative co-creation process presented includes a set of methods, tools, and content to increase the flow of knowledge, skills, and balance between the various stages within the learning cycle. The findings reflected here can benefit both teachers' practice at HEIs and researchers as a source for further analysis and the relevance of the methods used.

\section{Research results and discussion}

Streamlining the process of entrepreneurship higher education in shaping an entrepreneurial mindset, communication skills and the professional competencies necessary for working in a multicultural environment was one of the significant challenges of the ECMT+ Strategic Partnership Project. This study focuses on two-week intensive workshops (IPs) aimed at working out practical methods and tools for practice-oriented and result-driven entrepreneurship education to support learning and teaching processes in higher education. During the three pilot cycles, the participants totalled 147 students representing 16 nationalities from countries in Europe, 'Euro-Asia', East and South Asia, and North Africa. The workshop participants were asked to create business ideas to solve real problems and generate business models for ventures contributing to sustainable development for the local urban (or rural) environment. Inclusion of all inhabitants (mainly the needs of immigrants and refugees) and the development of social entrepreneurship 
that focuses on creating a positive social impact rather than creating as much financial profit as possible also had to be considered. The students received input from teachers, practitioners and young entrepreneurs from various backgrounds while working in diverse, multicultural teams. To gain hands-on experience, the workshop participants had to explore theoretical inputs in a purposeful way outside the classroom through a one-day field trip (respectively in Joensuu in Finland, Berlin in Germany, and Lyon in France) looking for inspirations for business ideas. In turn, on the university campus, students had the opportunity to observe each other, collaborate, test business concepts, compare their solutions and experience hands-on learning with tools and innovative equipment (e.g. ViNN:Lab at the TH Wildau).

Students were given a balance of practical experience and theoretical content during the IPs to encourage them to adopt a wide range of issues and methods in entrepreneurship education. To improve the process of competence development, theoretical and practical material was divided into six areas of activity, the so-called teaching 'formats', namely: learn it, do it, present it, test it, pitch it and evaluate it. These activities were a kind of guide to facilitate orientation in a wide range of content (the curriculum provided for 60 teaching hours) and help in the effective learning of business issues. For example, the "do it" format included activities involving the direct engagement of students, interactive communication and commitment among teams, such as prototyping the business idea, a student-team field trip, collection of open questions, preparation of user tests, looking for feedback, business idea iteration, utilisation of customer observation methods as well as preparation of the marketing campaign and financial plan. The competencies of the team members (or their absence) in areas of the division of tasks, decision making, respect for different values and behaviours, overcoming cultural prejudices, as well as shared responsibility for tasks and time management, were crucial for achieving the expected final results (Badzińska, Timonen, 2019: 13-15). It is crucial in each teaching process to clearly define tasks, goals and expected outcomes. For this reason, milestones were defined for each day of the two-week workshops to encourage students to perform the tasks effectively and share experiences with other teams.

The variety of teaching methods and tools used and learning styles provided a framework for the experiential learning process. Kolb's Experiential Learning Theory (1984) and the new Kolb Learning Style Inventory 4.0 (Kolb A.Y., Kolb D.A., 2013) were adopted throughout the whole teaching-learning process as a powerful foundational approach to all forms of learning, development and change. The knowledge and competency development process during the IPs consisted of the following stages: Initiating \& Inspiring, Imagination, Experiencing, Reflecting, Analysing \& Evaluating, Conceptualisation, Thinking \& Designing, and Action \& Cooperation, with Balancing as an essential activity at every stage of the process (see Figure 1).

The scheme is practical and visual, and it organises development activities in a logical form that reflects the process of creating innovative business models. These stages of the learning cycle contain several activities conducted and managed by the ECMT+ partners to justify the status of experiential learning and teaching. Examples of activities are outlined below:

1. Initiating \& Inspiring: developing preliminary ideas in the pre-IP framework; preparing a collective video of national students' teams using local background; acquiring a basic knowledge of entrepreneurship and business modelling; focusing on new 
Figure 1. The stages of the experiential learning cycle applied within the ECMT+ Intensive Programmes: 2017-2019

Source: own study based on ECMT+ IPs and an adaptation of Kolb Learning Styles Inventory 4.0 (Kolb A.Y., Kolb D.A., 2013)

learning opportunities and intercultural collaboration; creating entrepreneurial ideas for a local business.

2. Imagination: presenting business ideas in a "market" format (posters, talk) for other teams; discovering competing ideas; converging and selecting the most exciting ideas by participants; focusing on international teamwork, challenges and new experiences.

3. Experiencing: looking for business inspirations through a one-day field trip; considering a range of possible options and business solutions based on personal experience, acquired knowledge and cultural background; joining a team with "the best business idea"; conclusion of the team contract and decision making; sharing information based on subjective experience; collecting feedback and building relationships with other course participants; focusing on concrete experience by others.

4. Reflecting: connecting experiences and ideas through sustained reflection; taking time to intentionally consider multiple perspectives and the factors involved (e.g. learning content, aims, outcomes, environment); assessing the new experience gained; focusing on participatory observation and milestones.

5. Analysing \& Evaluating: exploring and collecting data; verifying market demand for one's business idea; assessing new knowledge and information gained; focusing on data, customer needs, and unique business solutions.

6. Conceptualisation: integrating experience and newly acquired knowledge into existing schemas and theoretical foundations; creating customer profiles and value propositions; generating a rough concept of the business model; focusing on the full concept development. 
7. Thinking \& Designing: using rational thought, research findings, disciplined logic or mathematics to generalise; exploring, testing, experimenting, prototyping and designing; focusing on business model iteration.

8. Action \& Cooperation: asking for feedback and support on the prototype; taking direct action to achieve a common goal; cooperating and engaging in solving the diagnosed problem to achieve expected outcomes; practising business ideas during the competition and public presentation of the concept; highlighting and awarding the best solutions.

9. Balancing: seeking a balance of practical experience and theoretical background; asking for feedback by IP participants and teachers; evaluating the learning outcomes; conducting critical analysis and consequences of actions; developing and improving curricula by implementing experiential learning activities; focusing on flexibility and utility (Badzińska, 2019: 52-53).

The activities indicated above provide steps for an iterative and participatory co-creation process of a business model based on the experiential learning cycle. This framework aims to visualise and shed light on the challenges of result-driven entrepreneurship education and help identify, prioritise, and execute the critical pathways crucial to achieving a common goal. Specifically, the experiential learning process model advanced here can be used to inspire future theoretical and empirical research efforts in the field of entrepreneurship education.

It should be emphasised that interdisciplinarity and inclusiveness were a crucial part of the entire learning process. The teams' high level of commitment to achieve their goals and their healthy competition point to measurable benefits of intercultural entrepreneurship education. The course participants could combine their prior practical experience with the knowledge acquired during the workshops to explore ways to actual business

Figure 2. Examples of business concepts developed by international students within the ECMT+ Intensive Programmes

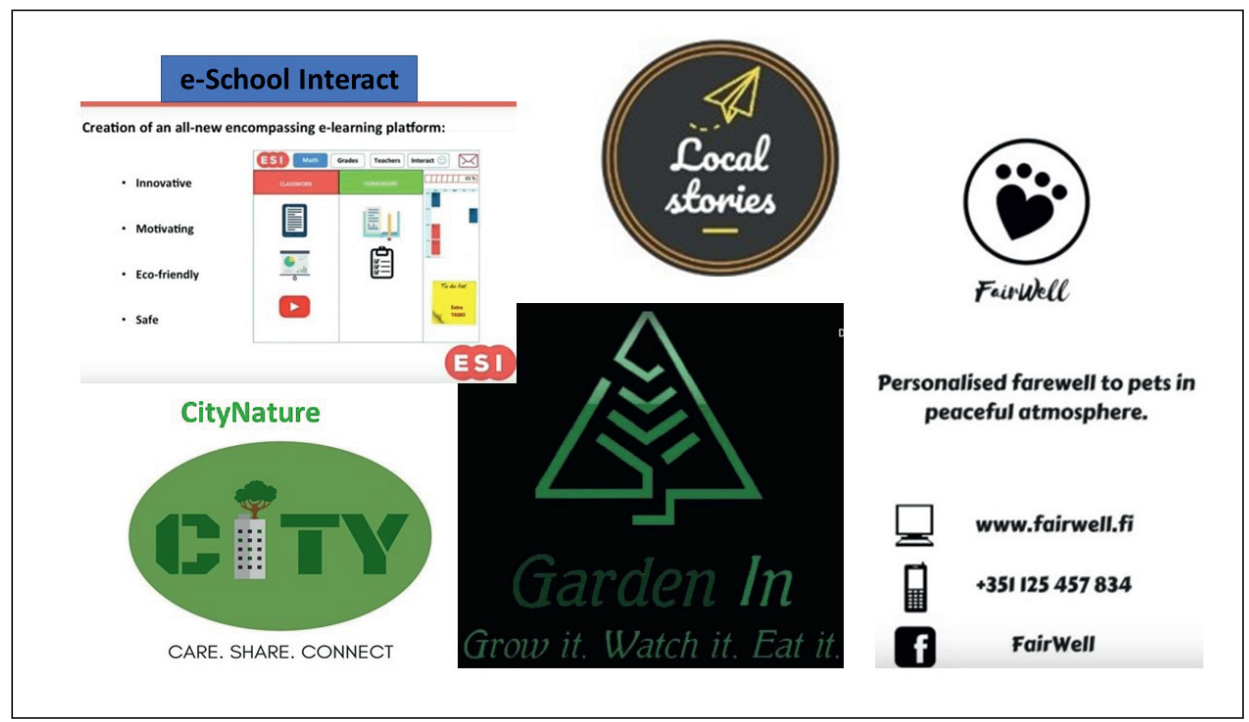

Source: author, based on the ECMT+ Project, student work, www.ecmt-plus.eu/student-work/ 
modelling through the experiential learning approach. The teams' work resulted in business solutions taking into account local communities' needs with a special emphasis on sustainable life-cycle thinking, inclusiveness, and well-being (see Figure 2). Another example is the concept of the "e-School Interact" to create an all-new encompassing e-learning platform to increase levels of innovation, motivation, eco-friendliness, and safety. In turn, several concepts were applied to "green" communities.

An example of this is the "City Nature" mobile application which aims at providing a simple infrastructure among urban gardening communities and supporting knowledge sharing on sustainable gardening. The "Garden In" concept offered a similar solution that encouraged growing herbs and vegetable farming, calling for "grow it, watch it, eat it". On the other hand, the "Local Stories" application was a solution to facilitate travellers' access to local people to learn unique and unusual curiosities about the place visited. In contrast, a completely different solution was offered by the emotional concept of "Fairwell" appealing to animal lovers. Based on one student's experience of not being able to say goodbye to a dying animal, team members decided to create a local community offering a personalised farewell to pets in a peaceful atmosphere.

It is worth noting that when learning entrepreneurship, students need to be offered opportunities that encourage them to be active and committed to achieving their goals. Creativity and innovation potential do not grow without challenges and real-life engagement. However, proper practice and the right training can provide skills and knowledge and create compelling solutions. Undoubtedly, in developing competencies, learners themselves must take responsibility for the learning process. This should be participatory, involving and challenging in a way that requires critical thinking and problem-solving skills (Badzińska, Timonen, 2020: 7).

To summarise, an essential advantage of the intensive entrepreneurship workshops was reciprocal learning - an opportunity to learn and experience a different perspective on the same issues and exchange views. It can be emphasised that the diversity of teachers and students has become a vital asset of the experiential learning process and creative thinking by developing business solutions. However, the research found that the pathways of teamwork, the mutual responsibility for creating and implementing solutions taking into account the needs of the local community can vary considerably depending on the government's support policy and the involvement of entrepreneurial ecosystem entities.

\section{Conclusions}

The more demanding operational environment is making HEIs rethink how they can educate effectively, meet the needs of a future working life and the rapidly changing needs of society. Nowadays, the world's economic and social changes show the importance of developing an entrepreneurial mindset and the creativity skills suitable for operating in an increasingly turbulent environment (which includes the COVID-19 pandemic). This has radically changed the conditions and possibilities of a practical approach to teaching entrepreneurship (e.g. field research, student internships in enterprises, face-to-face meetings with founders).

Educational practice confirms that there is not one correct teaching model but alternative strategies for university-based entrepreneurship education. Furthermore, the key to successful entrepreneurship education is to find the most effective ways to manage teachable 
skills and identify the best match between curricula, teaching techniques and market demands. This implies that students must acquire various knowledge bases and skills to successfully compete on the market both as entrepreneurs and employees of other companies.

The interdisciplinary activities developed by the ECMT+ project partners shed light on the complementarity of business, entrepreneurship and intercultural collaboration in educating students. As part of the programme activities, coaches were stimulated to navigate complex tasks and creative processes, develop critical thinking, cooperation, and goal-oriented learning. This approach aimed to prepare students for a business model generation; it allowed them to explore entrepreneurial opportunities in their universities and the external environment where their interdisciplinary knowledge and practical competencies can be the main strength in problem-solving.

Based on the participant-observation method's outcomes, reflections and opinions of the intensive programme participants all have confirmed that intercultural collaboration and result-driven entrepreneurship education brought the expected results. The variety of applied teaching methods, tools and content found the considerable approval of workshop participants. The healthy competition, team involvement, and well-coordinated work by the coaches provided a full sense of creating a unique solution and merging individual members into a team. The development process formed a hermeneutical circle where understanding and commitment grew throughout the reflective process and where the experienced reality was transformed into learning (Badzińska, Timonen, 2019: 9). However, it should be noted that the quality of the learning process depends not only on the pedagogical approach and the expert knowledge represented by teachers but, above all, on the involvement and internal motivation of the course participants themselves.

Integrating research findings into entrepreneurship education can be an essential path for improving entrepreneurial teaching and learning practice. Such an approach can contribute to developing and spreading innovative pedagogies and adjusting appropriate teaching tools and methods.

\section{References}

Bacigalupo, M., Kampylis, P., Punie, Y., Van den Brande, G. (2016). EntreComp: The Entrepreneurship Competence Framework. Luxembourg: Publication Office of the European Union. EUR 27939 EN.

Badzińska, E. (2019). Knowledge acquisition and business modelling using experiential learning approach to entrepreneurship. European Journal of Social Sciences Education and Research, 6(2), 48-56.

Badzińska, E. (2017). Evaluation of a Multicultural Approach to Teaching Entrepreneurship: Selected Research Results within the Framework of the ECMT+ International Project. European Journal of Social Sciences Education and Research, 11(2), 320-327.

Badzińska, E., Timonen, L. (2020). Exploring the University-based Entrepreneurial Activities in International Collaboration: Development Cases of HEIs. Journal of Intercultural Management, 12(2), 1-30.

Badzińska, E., Timonen, L. (2019). Entrepreneurial Mindset and Multicultural Communication Skills: a Reflection on the ECMT+ Intensive Programme. Zeszyty Naukowe Politechniki Poznańskiej. Organizacja i Zarządzanie, 79, 5-19.

Bechard, J.P., Toulouse, J.M. (1998). Validation of a didactic model for the analysis of training objectives in entrepreneurship. Journal of Business Venturing, 13(4), 317-332.

Block, Z., Stumpf, S.A. (1992). Entrepreneurship education research: Experience and challenge. In: D.L. Sexton, J.D. Kasarda (eds.), The state of the art of entrepreneurship. Boston, MA: PWS-Kent Publishing, 17-45. 
Bond, G., Le Pontois, S., Timonen, L. (2019). ECMT+ Entrepreneurship and Communication in Multicultural Teams: Learning Pathways for Students and Staff. Publications of Karelia University of Applied Sciences C: Reports, 63.

Bratnicki, M., Dyduch, W., Kozłowski, R., Zbierowski, P., Gabryś, B.J. (2007). Nauczanie przedsiębiorczości w Polsce i na świecie. In: Kierunki studiów ekonomicznych - nowe uwarunkowania $i$ wyzwania. Katowice: Wydawnictwo Akademii Ekonomicznej im. K. Adamieckiego w Katowicach, 83-92.

Cieślik, J. (2010). Przedsiębiorczość dla ambitnych. Jak uruchomić własny biznes?. Warszawa: Wydawnictwa Akademickie i Profesjonalne.

Cieślik, J. (2008). Kształcenie w zakresie przedsiębiorczości na poziomie akademickim. Czasopismo Edukacja, 2(102), 23-32.

Czakon, W. (2015). Zastosowanie studiów przypadku w badaniach nauk o zarządzaniu. In: W. Czakon (ed.), Podstawy metodologii badań w naukach o zarządzaniu. Warszawa: Wolters Kluwer Polska, 189-208.

Fayolle, A. (2013). Personal views on the future of entrepreneurship education. Entrepreneurship \& Regional Development, 25(7-8), 692-701. doi: 10.1080/08985626.2013.821318

Fayolle, A. (2005). Evaluation of entrepreneurship education: Behavior performing or intention increasing. International Journal of Entrepreneurship and Small Business, 2, 89-98. doi: 10.1504/ IJESB.2005.006072

Fayolle, A., Gailly, B. (2013). The Impact of Entrepreneurship Education on Entrepreneurial Attitudes and Intention: Hysteresis and Persistence. Journal of Small Business Management, 53(1), 75-93. doi: $10.1111 /$ jsbm. 12065

Gaweł, A., Pietrzykowski, M. (2015). Edukacja akademicka w postrzeganiu przedsiębiorczości i kształtowaniu intencji przedsiębiorczych. Problemy Zarządzania, 13(1(2)), 41-55.

Guerrero, M., Urbano, D. (2011). The Creation and Development of Entrepreneurial Universities in Spain: An Institutional Approach. New York: Nova Publishers.

Heinz, K., Chylková, M., Nenička, L. (2018). Significance of ECMT+ Participants' Feedback for their Future Entrepreneurial Careers within the EU. In: M. Staníčková, L. Melecký, E. Kovářová, K. Dvoroková (eds.), Proceedings of the 4th International Conference on European Integration 2018. Ostrava: VŠB-Technical University of Ostrava, 2018, 447-456.

Katz, J.A. (2003). The chronology and intellectual trajectory of American entrepreneurship education. Journal of Business Venturing, 18(2), 283-300. doi: 10.1016/S0883-9026(02)00098-8

Kilar, W., Rachwał, T. (2019). Changes in Entrepreneurship Education in Secondary School under Curriculum Reform in Poland. Journal of Intercultural Management, 11(2), 73-105. doi: 10.2478/ joim-2019-0010

Kirby, D.A. (2004). Entrepreneurship education: can business schools meet the challenge?. Education + Training, 46(8-9), 510-519. doi: 10.1108/00400910410569632

Kirby, D., Guerrero, M., Urbano, D. (2011). Making Universities More Entrepreneurial: Development of a Model. Canadian Journal of Administrative Sciences, 28, 302-316.

Kolb, D.A. (1984). Experiential Learning: Experience as the Source of Learning and Development. Englewood Cliffs: NJ: Prentice-Hall.

Kolb, A.Y., Kolb, D.A. (2013). The Kolb Learning Style Inventory 4.0. A Comprehensive Guide to Theory, Psychometrics, Research on Validity and Educational Applications. Experience Based Learning Systems, Inc.

Kuratko, D.F. (2005). The Emergence of Entrepreneurship Education: Development, Trends, and Challenges. Entrepreneurship Theory \& Practice, 577-597.

Kwiatkowski, S. (ed.). (2018). Kompetencje przyszłości, t. 3. Warszawa: Fundacja Rozwoju Systemu Edukacji.

Lackéus, M. (2015). Entrepreneurship in Education. What, why, when and how. Entrepreneurship360 Background Article. OECD.

OECD. (2012). A Guiding Framework for Entrepreneurial Universities. Retrieved from: http://www. oecd.org/site/cfecpr/EC-OECD\%20Entrepreneurial\%20Universities\%20Framework.pdf

Matlay, H. (2008). The impact of entrepreneurship education on entrepreneurial outcomes. Journal of Small Business and Enterprise Development, 15, 382-396. 
Matusiak, K.B., Guliński, J., Cieślik, J., Skala-Poźniak, A. (eds.). (2011). Edukacja dla przedsiębiorczości akademickiej. Warszawa: PARP.

Merriam, S.B. (1998). Qualitative Research and Case Studies Applications in Education. San Francisco: Jossey-Bass Publications.

Patton, M.Q. (2002). Qualitative research and evaluation methods. $3^{\text {rd }}$ ed. Thousand Oaks: Sage Publications.

Rachwał, T. (2019). Przedsiębiorczość jako kompetencja kluczowa w systemie edukacji. In: T. Rachwał (ed.), Kształtowanie kompetencji przedsiębiorczych, t. 5. Warszawa: Wydawnictwo FRSE, 16-34.

Raposo, M., Paço, A. (2011). Entrepreneurship education: Relationship between education and entrepreneurial activity. Psicothema, 23(3), 453-457.

Salzano, C., Bahri, S., Haftendorn, K. (2006). Towards an entrepreneurial culture for the twenty-first century: stimulating entrepreneurial spirit through entrepreneurship education in secondary schools. ILO and UNESCO. Retrieved from: https://unesdoc.unesco.org/ark:/48223/pf0000147057

Sánchez, J.C. (2013). The impact of an entrepreneurship education program on entrepreneurial competencies and intention. Journal of Small Business Management, 51, 447-465.

Shane, S., Venkataraman, S. (2000). The promise of entrepreneurship as a field of research. Academy of Management Review, 25(1), 217-226.

Szafrański, M., Goliński, M., Simi, H. (2017). The acceleration of development of transferable competences. Kokkola: Centria University of Applied Sciences.

Świeszczak, K. (2016). Uwarunkowania skuteczności działania inkubatorów przedsiębiorczości. Łódź: Wydawnictwo Uniwersytetu Łódzkiego.

Wach, K. (2013). Edukacja na rzecz przedsiębiorczości wobec współczesnych wyzwań cywilizacyjno-gospodarczych. Przedsiębiorczość - Edukacja [Entrepreneurship - Education], 9, 246-257.

Welsh, D.H.B., Tullar, W.L. (2014). A model of cross-campus entrepreneurship and assessment. Entrepreneurship Research Journal, 4, 95-115.

Welsh D.H.B., Tullar, W.L., Nemati, H. (2016). Entrepreneurship education: Process, method, or both?. Journal of Innovation \& Knowledge, 1(3), 125-132. doi: 10.1016/j.jik.2016.01.005

Yin, R.K. (2014). Case Study Research Design and Methods. (5 ${ }^{\text {th }}$ ed.). Thousand Oaks, CA: Sage Publications.

Zioło, Z. (2012). Miejsce przedsiębiorczości w edukacji. Przedsiębiorczość - Edukacja [Entrepreneurship - Education], 8, 10-23.

Ewa Badzińska, $\mathrm{PhD}$ in economics in management sciences, assistant professor in the Faculty of Engineering Management at the Poznań University of Technology. Her research interests include technological entrepreneurship, technology start-ups, business modelling, entrepreneurial ecosystems, academic entrepreneurship, entrepreneurship education, enterprise competitiveness, and business communication. She is the author or co-author of four books and more than 70 journal articles, book chapters and conference articles.

ORCID: https://orcid.org/ 0000-0002-2621-976X

\section{Address:}

Politechnika Poznańska

Wydział Inżynierii Zarządzania

ul. Rychlewskiego 2

60-965 Poznań, Polska

e-mail: ewa.badzinska@put.poznan.pl

\section{Acknowledgements and financial disclosure}

I would like to express my gratitude to all ECMT+ Project Partners, Students, and Entrepreneurs involved in the Intensive Programmes 2017-2019 and provided valuable feedback on the international Strategic Partnership Project. The article processing charges were funded by the Faculty of Engineering Management from the Poznań University of Technology, grant number 0812/SBAD/0616. 